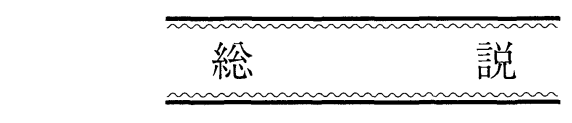

\title{
イオン注入による表面層の改質
}

$$
\text { 岩木 正 哉* }
$$

\section{Surface Layer Modification by Ion Implantation}

\author{
Masaya IW AKI*
}

Ion implantation, which has made great progress as a method of impurity doping in semiconductors, has lately attracted considerable attention as a surface modification process for metals, ceramics, polymers and other materials. This report reconsiders ion implantation processing from the standpoint of surface layer treatments (i.e. by comparing it with physical or chemical vapour deposition), and a related technique known as ion beam enhanced deposition is introduced. The ability of high fluence implantation to form new metastable surface alloys and compounds is described and as an example the reasons for improvement in the wear resistance of steels by nitrogen implantation are explained.

Key Words : Ion, Ion Implantation, Thin Film, Mixing, PVD, CVD

\section{1.は じめに}

半導体, 特にシリコンへの不純物添加法として研究・ 開発されてきたイオン注入法は, 今日 LSI 製造工程に 特ける不純物添加などで重要な役割を果たしている。こ の技術がなかったら現在の LSI は存在しなかったとい っても過言ではない。

半導体へのイオン注入で利用されてきたエネルギーは 通常 $200 \mathrm{keV}$ 以下であった。この技術を更に発展させ $1 \mathrm{MeV}$ 以上のエネルギーを利用すると, 新しい素子の 開発や素子の微細化に伴って発生した種々の問題を解決 でさる可能性があることと指摘されている1。この高エ ネルギーイオン注入の応用は堆積薄膜層を通して不純物 を添加したり，基板内に埋め込みシリサイドなどの金属 層や酸化層などの絶縁層を形成することなどが挙げられ ている。これらの手法の開発は金属などの表面改質に新 たな道を拓くものと期待されている。

金属を対象としたイオン注入技術は，表層合金化やセ ラミックス化などを行い，金属表面層の耐食性や耐摩耗 性を改善することが目標とされた2)。セラミッックスへの イオン注入では, 表層を異種セラミックスにすることや 金属化などが目標であっだ)。これはセラミックス/セ ラミックス接合部の強化やセラミックスの脆性を表層金

* 理化学研究所 ( RIKEN [The Institute of Physical and Chemical Research] (2-1, Hirosawa, Wako-shi, Saitama 351-01)
属化で補らためである。

最近ポリマーへのイオン注入が注目され始めた。ポリ マーは無機材料よりも遥かに多く存在する材料である。 この材料は放射線損傷に弱いといわれ，したがってイオ ンビーム照射では破壊効果が大きく, 粒子添加効果は得 難いと考えられていた。しかし，これまでの幾つかの研 究結果では炭化現象が認められるものの, 明らかな不純 物ドーピング効果が得られることや新しいラジカルがで きることなどが示された4)。

純粋炭素材へのイオン注入も活発に研究が進められて きた。単結晶炭素であるダイヤモンドは装飾品としても 工具材としても魅力的な材料である。これまで工具とし ての寿命の改善や $p-n$ 接合の形成などが試みられてき だ)。また，炭素材は他の無機材料に較べ軽量であり， 化学反応しにくい材料であるため人工藏器材料としての 利用も検討されている。

このようにイオン注入法は半導体の分野から徐々に裙 野を広げ，広大な材料科学の領域に浸透しつつある。こ こではイオン注入法と現在利用されている PVD, CVD 技術の比較を装置の上から捉え直し，イオン注入法の利 点を利用したイオンビーム増速蒸着などの関連技術を表 層処理と表面被覆の観点から述べる。また, 高濃度イオ ン注入に持いて形成される新しい物質やイオン注入に伴 う付随効果, また具体的改質例については耐摩耗性の改 善機構について述べる。 


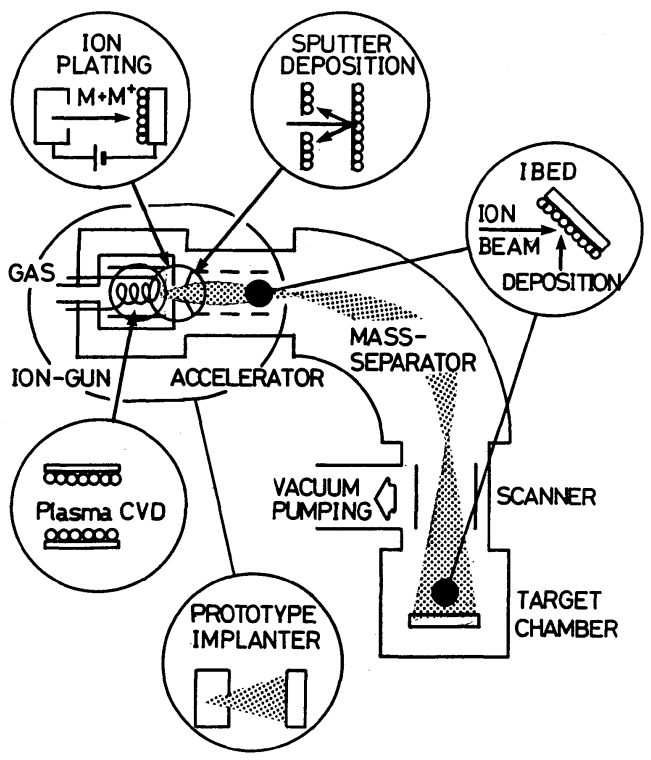

Fig. 1 Outline of an ion implanter.

\section{2. イオン注入装置にみる PVD, CVD}

イオン注入法とは真空中 $\left(10^{-4} \mathrm{~Pa}\right)$ で添加したい粒子 をイオン化し, 静電界などで加速し, 固体基板に照射す ることによる粒子添加法である。図1にイオン注入装置 の概要を示す ${ }^{6)}$ 。本装置は, 添加したい粒子をイオン化 するイオン源, イオン源よりイオンを取り出し加速する 加速器, 必要なイオンを選別する質量分離器, 照射基板 面上でイオンビームの均一性を保つためのイオンビーム 走査器, イオンビームを照射する注入室叔よび全系を真 空にする排気装置から構成されている。現在利用されて いるェネルギーは数 $10 \mathrm{keV}$ から数 $100 \mathrm{keV}$ であるが, イオンビーム技術の進展と共に $\mathrm{keV}$ から $\mathrm{MeV}$ へと利 用できるエネルギー範用を広げている。

このイオン注入装置とプラズマ CVD 装置就よび PVD 装置などを比較する。結論として言えばイオン注
入装置のイオン源は一種のブラズマCVD 装置である。 すなわち，イオン源内に導入された気体は電子と衝突し イオン化するが，イオン化室内は電子とイオンが共存す るブラズマの世界である。イオン注入の場合はこのブラ ズマからイオンを取り出し加速する。一方，ブラズマか らイオンを取り出さず，イオン化室内にブラズマをとじ 込め，内壁に薄膜をコーティングすることはプラズマ CVD の一種である。したがって，アセチレンガスを導 入し炭素イオンビームを得ようとする場合, 放電条件に よっては炭素ビームが得られずイオン化室内壁への炭素 薄膜コーティングが拉こる。

イオン化室内へのガスのフロー量が多く，イオンの取 り出しロからイオンと多量の中性粒子が出る場合は, 一 種のPVD, すなわち，イオン化プレーティングと等価に なる。また，取り出したイオンビームが発散し，引き出 乙電極に照射されると電極材料がスパッタリングされイ オン源外壁にコーティングされる。これがイオンビーム スパッタ蒸着である。イオンビームが取り出されたとし て, 質量分離器の前までを一つのシステムとして利用す る方法が簡易型イオン注入器である。すなわち, 窒素専 用イオン注入装置はこのシステムで市販されている。

近年盛んに研究され始めたイオンビーム照射と真空蒸 着を併用したダイナミカルミキシング（イオンビームア シスト蒸着，イオンビーム増速蒸着などと言われる）は イオン注入装置, もしくは簡易型イオン注入装置の注入 室に蒸着装置を有したものである。この蒸着法には電子 ビーム蒸着やスパッタ蒸着などがあり, 使用法によって 選択されている7。

ともかくイオン注入法は道具としてのイオンの発生, イオンをビームとして高性能化させる加速器や質量分離 器, 注入室といら処理室の距離が離れ, それらが独立に 制御される。したがって，材料創成に打いて制御珄は優 れているが処理能力は他の PVD P CVD 比べて劣る。 逆に言えば PVD や CVD は処理能力は比較的高いが制

Table 1 Comparison between ion implantation, IBED (ion beam enhanced deposition), PVD (physical vapour deposition) and CVD (chemical vapour deposition).

\begin{tabular}{l|c|c|c|c}
\hline Treatments & \multicolumn{1}{|c|}{ Ion Implantation } & \multicolumn{1}{c|}{ IBED } & CVD \\
\hline Features & $\begin{array}{l}\text { Particle doping with } \\
\text { non thermal equilibrium }\end{array}$ & $\begin{array}{l}\text { Coating at } \\
\text { room temp. }\end{array}$ & $\begin{array}{l}\text { Coating at } \\
\text { low temp. }\end{array}$ & $\begin{array}{l}\text { Coating at } \\
\text { high temp. }\end{array}$ \\
\hline $\begin{array}{l}\text { Treating } \\
\text { Temperature }\end{array}$ & $\begin{array}{l}\text { Free \& possible at } \\
\text { room temperature }\end{array}$ & $\begin{array}{l}\text { Free \& possible } \\
\text { at room temp. }\end{array}$ & a few $100^{\circ} \mathrm{C}$ & $\sim 1000^{\circ} \mathrm{C}$ \\
\hline $\begin{array}{l}\text { Thickness } \\
\begin{array}{l}\text { Treating } \\
\text { Speed }\end{array}\end{array}$ & $0.1 \sim 1 \mu \mathrm{m}$ & $0.1 \sim$ a few $\mu \mathrm{m}$ & a few $\mu \mathrm{m}$ & a few $\mu \mathrm{m}$ \\
\hline $\begin{array}{l}\text { Control of } \\
\text { crystalline }\end{array}$ & Low & Low Midde & Middle & High \\
\hline Pressure & $0.0001 \mathrm{~Pa}$ & $0.01 \sim 0.001 \mathrm{~Pa}$ & $\begin{array}{l}\text { Limited by } \\
\text { Temp. }\end{array}$ & $\begin{array}{l}\text { Limited by } \\
\text { Temp. }\end{array}$ \\
\hline
\end{tabular}


御性に劣ると言えるだろう。この従来法とイオン注入法 の谷間の技術, すなわちイオン注入の利点と PVD の利 点を合せ持った方法がイオンビーム增速蒸着であると考 えられる。これらの技術を比較した概要を表 1 に示す。

\section{3. イオン注入}

イオンビームと固体の相互作用を改質といら観点から 捉光ると, 三種の効果がある。第一の効果はイオンが数 $10 \mathrm{keV}$ で加速されたときの付着効果, 第二の効果は数 $\mathrm{keV}$ のイオン照射によるスパッタリング効果, 第三の 効果は数 $10 \mathrm{keV}$ 以上で照射されたときの注入効果であ る。しかし，これらの効果をエネルギーによって厳密に は区別できず, 多くの場合これらの効果は混合して認め られる。したがって，イオン注入法は第三の効果を利用 した粒子添加法であり，イオンビーム照射による表面層 の改質に打いて注入効果が大きい場合はエネルギーに関 係なくイオン注入もしくはイオン注入関連技術として位 置付けたい。

イオンが固体に照射され侵入すると，侵入したイオン は基板原子と弾性扣よび非弾性衝突を絽り返し, エネル ギーを失い固体内に止まる。图 2 に示すように，侵入し たイオンの飛跡の回りには衝突で弾き出された基板原子 が更に衝突を繰り返し，その結果として多量の照射損傷 が発生する。この非熱平衡下での粒子の侵入により固体 基板表層には新しい物質や構造が形成され，表面層は母 材と異なった性質を示すようになる。

注入したイオンの飛跡は侵入イオン毎によって異なる ため，イオンは分布をする。この注入イオンの分布形状 は図中に示すように，ある深さを最大濃度としたガウス 分布で近似できる8)。また，照射損傷の分布は注入イオ ンの最大濃度の深さょり浅い位置で最大になり, イオン
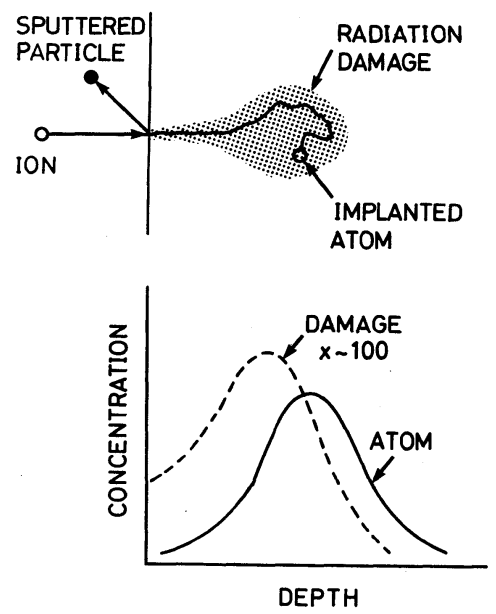

Fig. 2 Ion bombardment effects and depth distributions of implanted ions and damage.

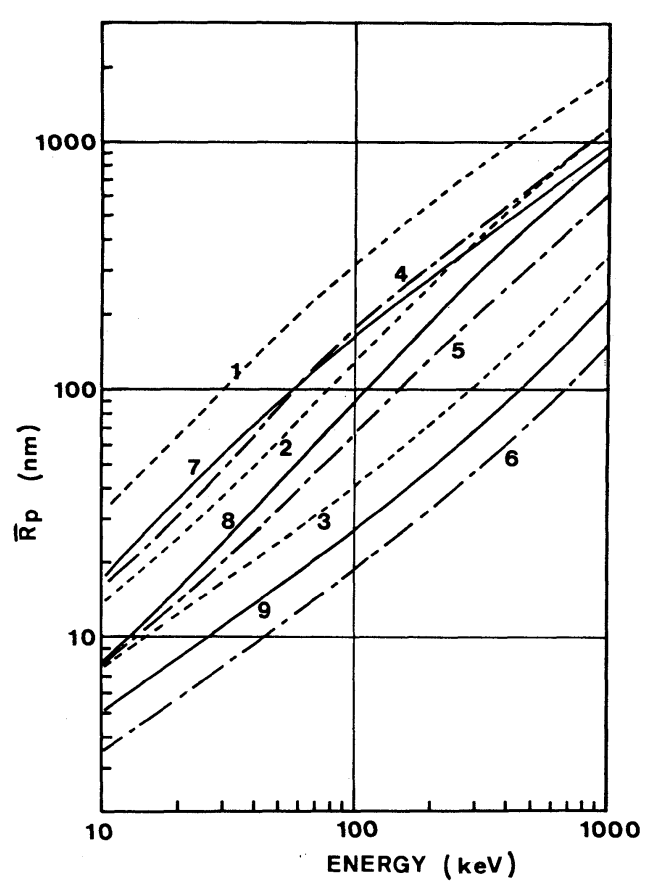

Fig. 3 Average projected range $\left(\bar{R}_{p}\right)$ of $B, \quad A l$ and $\mathrm{Sb}$ implanted in $\mathrm{Fe}, \mathrm{Al}$ and diamond.

$$
\begin{aligned}
& 1 ; \mathrm{B} \rightarrow \mathrm{Al}, \quad 2 ; \mathrm{Al} \rightarrow \mathrm{Al}, \quad 3 ; \mathrm{Sb} \rightarrow \mathrm{Al} \\
& 4 ; \mathrm{B} \rightarrow \mathrm{Fe}, \quad 5 ; \mathrm{Al} \rightarrow \mathrm{Fe}, \quad 6 ; \mathrm{Sb} \rightarrow \mathrm{Fe} \text {, } \\
& 7 ; \mathrm{B} \rightarrow \text { Dia., } 8 ; \mathrm{Al} \rightarrow \text { Dia., } 9 ; \mathrm{Sb} \rightarrow \text { Dia. }
\end{aligned}
$$

一個あたり数 100 個の原子を変移させる。

イオン注入により処理できる深さは注入イオンの分布 の最大濃度の深さが一つの目安になる。注入イオンの侵 入深さは, 基板, イオン種, また利用するイオンの加速 エネルギーにより決まる。図3に鉄, アルミニウム, ダ イヤモンドへ $\mathrm{B}, \mathrm{Al}, \mathrm{Sb}$ をイオン注入したときの最大濃 度の飛程をエネルギーの関数として示す。これまで利用 されてきた $100 \mathrm{keV}$ 前後のエネルギーでは最大濃度の深 さは $0.1 \mu \mathrm{m}$ 前後であるから処理深さも非常に浅い。今 後, $\mathrm{MeV}$ イオン注入が可能になれば $\mu \mathrm{m}$ オーダーに到 達し，PVDなどの従来法と同程度の処理深さが実現さ れる。そのため $\mathrm{MeV}$ イオン注入装置の開発への期待は 大きい。

イオン注入法もイオンビーム照射法の一つであるから スパッタリングが起こり，必ず表面が削り取られる。す なわち，イオン注入法は表面を削り取りながら粒子を添 加する方法である。したがって, 注入イオン分布へもス パッタリングの影響を考慮しなければならない。図4に $\mathrm{Fe}$ への Ti イオン注入, Alへの Nイオン注入の場合に 扣ける注入イオン分布を注入量の関数として示す。 $\mathrm{Fe}$ への Ti イオン注入に拈けるスパッタリング率を 3 atoms/ion, $\mathrm{Al}$ へのNイオン注入のものを 0.3 atoms/ ion とした。スパッタリング率が高いと注入イオン分布 

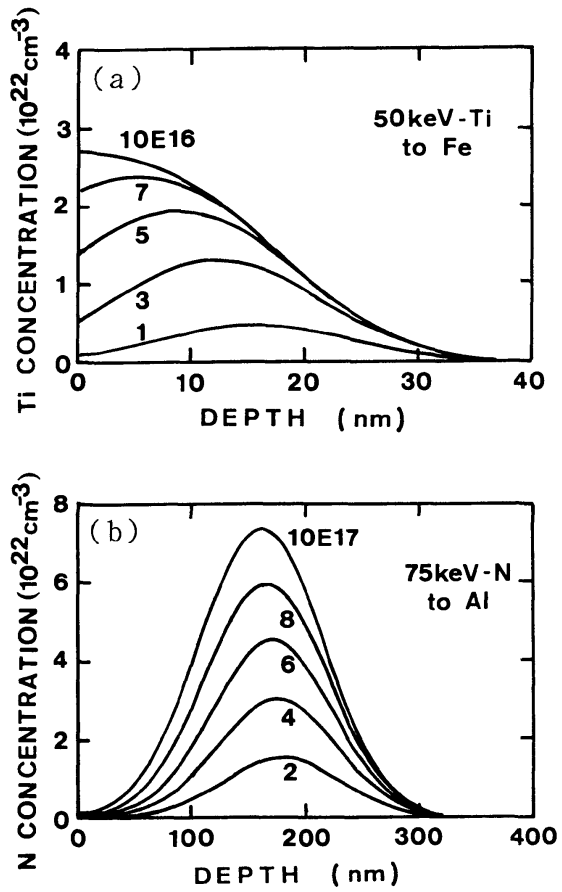

Fig. 4 Depth distributions of Ti implanted in $\mathrm{Fe}$ (a) and $\mathrm{N}$ implanted in $\mathrm{Al}$ (b) calculated by the modified range theory.

は注入量の増加と共にガウス分布から変形し, 最終的に は最大濃度が最表面に表れる。このような分布は10〜 $100 \mathrm{keV}$ でのイオン注入に拈いてすでに実験的に認めら れている。また， MeVイオン注入ではスパッタリング 率は小さくなり，分布への影響は少ないだろう。

一方, スパッタリング率が小さいと注入イオンの最大 濃度は母材原子濃度を越えることが予測される。しかし， 実験結果は注入イオン濃度が母材濃度を越えず, 内部か ら結晶成長することを示しだ9。この内部からの化合物 結晶成長がイオン注入法ならではの特徵であり, $\mathrm{MeV}$ イオン注入では新しい合金や化合物が埋め込める可能性 がある。

高濃度イオン注入に伴ら多量のスパッタリングは表面 をクリーニングし, 表面への残留ガスの吸着を促進させ る。吸着層内の原子はイオンビームにより基板内に添加 されることがある。これまでも $\mathrm{Fe}$ への $\mathrm{Ti}$ イオン注入 に特けるC の混入, $\mathrm{Al}$ への 混入などが認められている。これらの混入は注入室内の 高真空化や残留ガス成分制御で防ぐことができる。

ともかく, イオン注入装置の構成, 特よびこれらの照 射効果からイオン注入法は次のような特徵を有す。

(1)非熱平衡下での粒子添加プロセスであるから, 添加 したいイオンと添加する基板の組み合わせを自由に 選択できる。
(2)添加するイオンの深さを加速エネルギーで制御でき る。

(3)添加するイオンの量をイオンビーム電流密度と処理 時間で制御できる。

(4)質量分離をするため添加粒子の純度が良く，イオン ビーム走查により添加粒子の面上均一性が良い。 ただし，(2)，(3)についてはスパッタリング効果を考虑す る必要があり, (4)の質量分離による添加粒子の高純度化 は表面層改質には重要にならない場合もある。ともかく, イオン注入の最大の特徴は(1)である。

\section{4. イオン注入と膜形成}

イオン注入技術の重要な課題の一つがイオン種の多種 化である。理化学研究所で表層改質に利用したイオン種 は47種であり, 周期律表にある元素の約半分である。イ オンにはイオン自身の特徵があるようにイオンビームに も特徴がある。この種々の特徴があるゆ兄にイオンビー ムを作る上にも難易度がある。したがって，イオンビー ムにより粒子の直接添加が困難なものは, 薄膜形成とイ オンビーム照射を併用したイオンビームミキシングによ る表面層改質法が開発された。

イオンビームミキシング法は照射したイオンのカスケ 一ド衝突を主に利用する方法で, 薄膜原子と基板原子を 熱を用いないで混合する方法である。この方法によれば イオン注入で作成した表層と同様の表層を作成できる可 能性がある。ただしこの方法での改質する深さはイオン ビームの到達距離に依存する。

イオンビームを利用して改質深さを厚くする方法がイ オンビームアシスト蒸着扣よび増速蒸着法である。この 方法は蒸着しながらイオン注入を行うため原理的には膜 厚に制限はない。作成される薄膜の組成はイオンビーム 電流と蒸着速度に依存する。

これらの手法の概要を図 5 に示す6)。図中の(1)が直接 イオン注入であり，金属への金属イオン注入で準安定表 層合金の形成やセラミックスへの金属イオン注入で金属 埋込層の形成などである。(2)がイオンビームミキシング 法で薄膜を通してイオン注入することにより基板原子と 薄膜原子の混合層を形成する手法である。(3が界面ミキ シング法で, 薄膜と基板の界面付近のみを混合させる方 法である。(4)の手法がイオンビームアシスト蒸着やイオ ンビーム増速蒸着法であり, 真空蒸着とイオンビーム照 射（イオン注入）を同時に行ら方法である。

イオンビームアシスト蒸着とイオンビーム増速蒸着法 はあまり区別されずに使われている。したがって，今後 のためにこれらの用語を区別して扣きたい。アシスト蒸 着で利用するイオンビーム照射は利用したイオンの化合 物を形成しない場合のこととし，增速蒸着で利用するイ オンビームは添加イオンの化合物が形成される場合とし 
BOMBARDMENT RESULT

(a) DIRECT IMPLANTATION

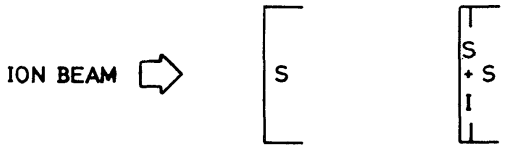

(b) ION BEAM MIXING

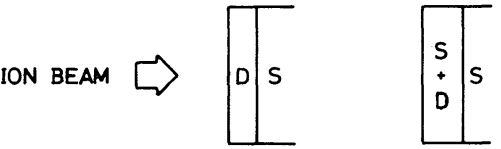

(c) INTERFACE MIXING
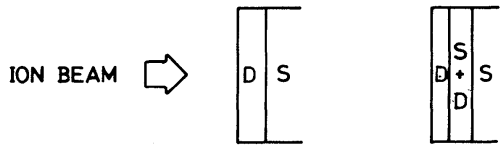

(d) ION BEAM ENHANCED DEPOSITION
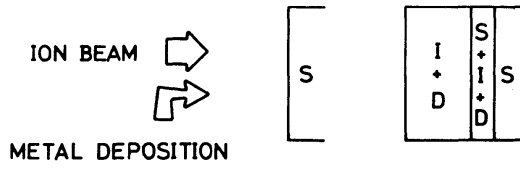

Fig. 5 Ion implantation and other processes related to it.

て定義して招きたい。したがって，前者は薄膜と基板の 密着性を向上させたり，膜の結晶性を制御するためのも ので，後者ではそれと同時に添加イオンの化合物も形成 される。ともかく, 電子ビームによる真空蒸着とイオン 注入を併用した技術は電動シェイバーの刃の処理に拈い て実用化されている。

以上のイオン注入プロセスと従来法の PVDを組み合 わせると図 6 に示すよらな種々の表面層処理プロセスが 考えられる。第一の方法がイオン注入法を前処理法とし て利用する方法である。すなわち，PVD などで形成す る薄膜の密着性を向上させるために単なるイオンビーム スパッタリングを利用せず，スパッタリングと新物質合 成とを同時に利用し膜質を向上させる方法である。すで に鉄鋼材料への $\mathrm{TiN}$ ューティングに怙いて前処理とし てNやTi イオン注入が，またアルミニウムへの AlN コ 一ティングに执いてNイオン注入が有用であることが証 明されている6)。

第二の手法が薄膜を通してイオン注入するイオンビー ムミキシングである。これを連続して行ら方法がイオン ビームアシスト蒸着もしくは増速蒸着である。また, オンビームミキシング層はイオン注入層と同様の性質を 持つため, 第一の手法と同様にミキシング㲊の上に PVD などにより高密着性の薄膜形成も可能であろう。

第三の手法が厚膜へのイオン注入である。ここで言う 厚膜は $1 \mu \mathrm{m}$ 程度の膜厚で, 薄膜は $0.1 \mu \mathrm{m}$ 程度である。 厚膜形成法は PVD, CVD や電気めっきなど数多くの手 法がある。厚膜へ通常のエネルギーでのイオン注入を行

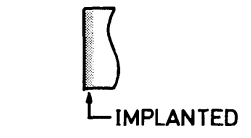

IMPLANTATION LITED DEPOSITION

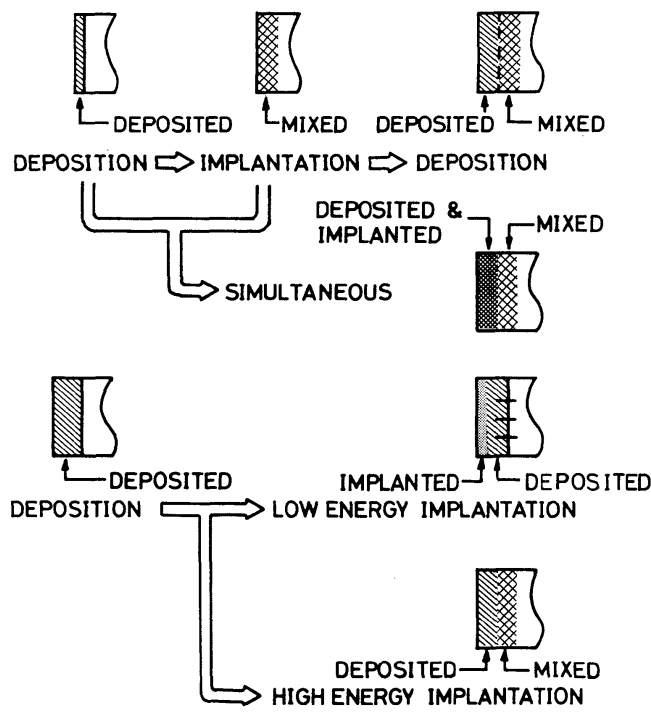

Fig. 6 Combination of ion implantation with other surface treatments.

らと，厚膜の表層のみが改質されると考兄られる。ただ し，イオン注入により発生した照射損傷の拡散距離が数 $\mu \mathrm{m}$ であるならば厚膜と基板の界面にイオンビーム照射 が影響を及ぼしているかもしれない。更に，粒界拡散が 起こりらる可能性も十分にある。また，高エネルギーイ オン注入では厚膜と基板の界面がイオンビームミキシン グによって混合でき，厚膜の構造制御の可能性もある。 ともかく，硬質クロミウムめっきへのNイオン注入では 耐食性, 耐摩耗性の改善が認められている6

\section{5. イオン注入による耐摩耗性改善例}

イオン注入により表面層の各種特性を改変した例は数 多い。なかでも，超硬合金，鉄鋼，チタン合金などの耐 摩耗性改善に関する研究は数多く試みられ，ベアリング 鋼やチタニウム合金製人工股関節などでは実用化されて いる ${ }^{10)}$ 。竜た，射出成形金型や各種工具に括いても実用 化試験が続けられて㧤り，一部に特いてはすでに実用化 されていると思われる。

耐摩耗性改善のために最も多く利用される注入イオン 種は窒素イオンである。特に鋼材への窒素イオン注入は 基礎研究から応用研究屯で広範囲に渡っている。この理 由は窒素イオンビームが容易に多量に得られること，イ オン窒化とイメージが重なることなどが挙げられる。し かし, 窒素イオン注入とイオン窒化は本質的に異なり, 
前者が非熱平衡処理であるのに対し，後者は熱平衡過程 を利用することである。生た，イオン注入では窒化層が 内部から形成され，基板温度や添加量が自由に制御でき るが，イオン窒化では窒化層は表面から形成され，処理 温度も高い。

イオン注入による処理深さを注入イオンの最大濃度が 存在する深さとみなすと, $0.1 \mu \mathrm{m}$ 前後が窒素イオン注 入による処理深さであろう。このような浅い改質層で耐 摩耗性が改善される理由を探るために, 数多くの研究が 行われた。これまで得られた共通した結果は, 以下の三 点に集約される。

(1)窒素イオン注入により表層硬化が起こる。

(2)摩耗試験中にイオン注入した窒素が内部深くに侵入 する。

(3)摩耗トラック上の組成分析結果は, 未注入材では認 められない酸素の混入がイオン注入材では認められ る。

(1)の表層硬化は窒化物の形成により説明できる。また (2)は摩耗試験中に発生する転位網を介して窒素が移動し た結果であると解釈されている。さらに(3)の酸素の混入 結果は窒素イオン注入材の中で摩耗率が未注入材に比べ 低下しているものについて認められているが，この理由 は明確ではない。

以上の結果と摩耗粉の解析結果などを総合すると窒素 イオン注入による耐摩耗性改善のメカニズムは次のよう にまとめられる。すなわち鉄鋼表層には窒素イオン注入 により「埋め込及窒化層」が形成される。この窒化層形 成汇より表層硬化が起こり, 初期摩耗率が低下する。こ の初期摩耗中に酸素が混入し，工学的には摩擦係数の低 下, 物理的には凝着が低下寸る。また, 低摩耗率中の摩 擦に特いて発生する転位を介して注入した窒素の一部が 内部へ移動する。転位を介した窒素の内部移動は埋め込 及窒化硬化層の厚化を進行させる。これらの現象は未注 入材の摩耗試験で認められた凝着摩耗が窒素イオン注入 により酸化摩耗に移行することを示している。したがっ て, 凝着 (シビア) 摩耗から酸化 (マイルド) 摩耗への 摩耗機構の移行が摩耗率の低下を導き, 耐摩耗性を向上 させていると考えられる。このような結果は窒素イオン 注入したチタン合金に和いても認められている。

これらの結果から窒素イオン注入で耐摩耗性向上が得 られる一つの条件は表面から酸化が抗こること，すなわ ら空気などに触れることである。この一つの証拠がチャ ックと棒材を利用した摩耗試験で認められた。これらの 材料と滑り接触条件は, チャック材は連続接触, 棒材は 接触と非接触（空気に触れている）の繰り返しである。 窒素イオン注入による耐摩耗性の改善は棒に対しては認 められるが, チャックに対しては認められていない。す なわち, これは空気に触れる条件ならば耐摩耗性が改善

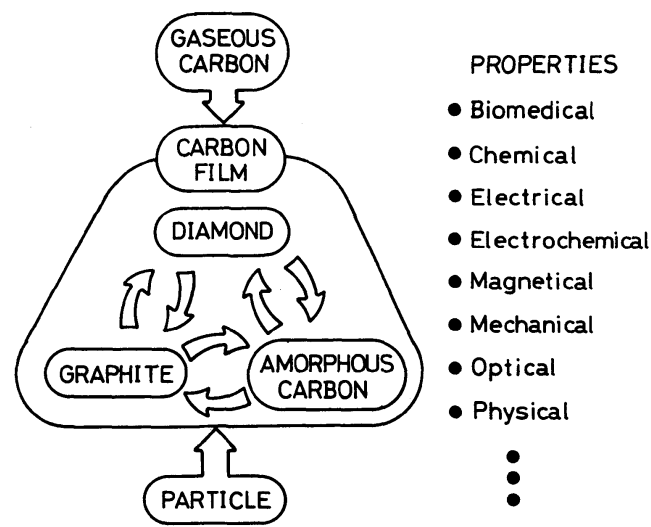

Fig. 7 Outline of ion beam processing for carbon thin films.

されることを示している。

ともかく，窒素イオン注入による耐摩耗性の改善の第 一条件は表層硬化であり, この鉄鋼の表層硬化度はイオ ン注入中の基板温度が関係している。また，耐摩耗性を 向上させる酸素の混入には注入した窒素の分布が関与し ていると考觉られ，更なる基礎研究が重要である。した がって, 窒素イオン注入鉄鋼の実用化にあたっては, $\mathrm{MeV}$ まで含めた注入エネルギー, 注入量や注入基板温 度などの注入条件の最適化を使用条件を含めて詳細な検 討を行う必要がある。

最近，イオン注入による炭素材の耐摩耗性改善に関す る研究が生体材料への応用の上で注目されている。炭素 材が生体適合性に優れていることや小型軽量, また低 $Z$ 数であるために注入したイオンの侵入深さが深いことな どがその理由に挙げられている。

イオン注入を含めたイオンビーム技術と炭素材の関係 を図 7 亿示す5)。現在最も盛んに研究されている関係は ガス状炭素から炭素薄膜の形成であり, ダイヤモンド薄 膜形成は最も注目されている課題である。形成された薄 膜の結晶性変換制御も重要な課題であるが, 研究例は少 ない。また, 炭素材への異種元素の添加は熱平衡過程で は限定されるため, 粒子添加へのイオン注入の役割は大 きいと思われる。ともかく，ここには広大な研究領域が 残されている。

イオン注入したグラッシィカーボン表層は比較的低注 入量で非晶質を示す。これは $\mathrm{Si}, \mathrm{Ge}$ など $\mathrm{N}$ 属元素で構 成された材料に共通する現象である。また，注入したイ オンの分布は通常ガウス分布を形成するが，稀に再分布 する場合がある。ともかく窒素イオン注入したグラッシ ィカーボンは耐摩耗性の向上を示し, その改善度は注入 エネルギーと関係し, 高いェネルギーほど良い。すでに $\mathrm{MeV}$ 注入に颃いて子良好な結果が得られ, この領域で は $\mathrm{MeV}$ イオン注入は有用であろう。 


\section{6.おわりに}

本稿ではイオン注入法による表面層改質の特色とその 周辺技術について概説した。詳細な解説は本特集号の他 の解説を参照していただきたい。イオン注入の特徵と社 会的認識の歴史と現状を振り返ると，“当面”イオン注 入技術は基礎研究が重要であり, 実用化にはイオンビー 么増速蒸着が有望であろう。直接イオン注入が多くの分 野で実用化されることを期待している。

(1988-5-2 受理)

\section{文献}

1）田村誠男；Semiconductor World, 6，(14），67（1987）
2）斎藤一男；金属表面技術，39，563（1988）

3）日置辰視；金属表面技術，39，586（1988）

4）岩木正哉; 静電気学界誌, $12,(3), 196$ (1988)

5）岩木正哉；二ューダイヤモンド，4，(1)，13（1988）

6）岩木正哉；実務表面技術，34，402（1987）

7) S.M. Rossnagel and J.J. Cuomo ; MRS BULLENTIN, 12, (2), 40 (1987)

8）岡部芳雄；アイオニクス, (90), 3 (1983)

9）岩木正哉; 表面, 25, 676 (1987)

10) P.Shioshansi ; Thin Solid Film, 118, 61 (1984)

\section{参考資料}

吉田清太，難波 進，岩木正哉監修; イオン注入表層改質技術 （サイエンスフォーラム, 1987)

岩木正哉；イオン注入，材料のプロセス技術 [1] 第 6 章, 材 料テクノロジーシリーズ 9 (東京大学出版会, 1987)

\section{用 語 解 説}

\section{平均投射飛程 (Average Projected Range)}

ターゲット材料に照射されたイオンは，ターゲット 構成原子等との衝突により, エネルギーを失い静止す る。その様子の概略図を図 1 に示す。イオンは $n$ 回 の衝突によりそれぞれ散乱され，それぞれの衝突に特 いて $r_{1} \sim r_{\mathrm{n}}$ の軌跡をとる。注入イオンは静止するま での全飛程 $R_{\mathrm{t}}$ は， $R_{\mathrm{t}}=\sum_{\mathrm{n}=1}^{\mathrm{n}} r_{\mathrm{n}}$ となり, この距離をイオ ンは実際に移動することになる。いま，イオンの入射 点と静止点とを結ぶと, そのベクトルの深さ方向 (四 中Y軸方向） 一の投影長さ $R_{\mathrm{p}}$ が存在する。入射イオ ンは一定のエネルギーをもって照射されるが，表層の 原子とはランダムな衝突パラメーターで衝突するので, $R_{\mathrm{p}}$ の值は一つの值ではなくある広がりをもった值と なる。この場合， $R_{\mathrm{p}}$ の統計的平均值を平均投射飛程 $\bar{R}_{\mathrm{p}}$ といい, その広がりを平均投射飛程の標準偏差 $\Delta \bar{R}_{\mathrm{p}}$ といい, ピーク値の $1 / \sqrt{\mathrm{e}}$ での広がりを示す。

平均投射飛程はイオンのエネルギー，原子番号，質 量数, ターゲットの原子番号, 質量数などによりその 值が決まる。実際の平均投射飛程の值はデータブッ $ク^{1), 2)}$ により簡単に求めることができる。一般的に， 平均投射飛程の值は, 最大 $1 \mu \mathrm{m}$ 程度である。

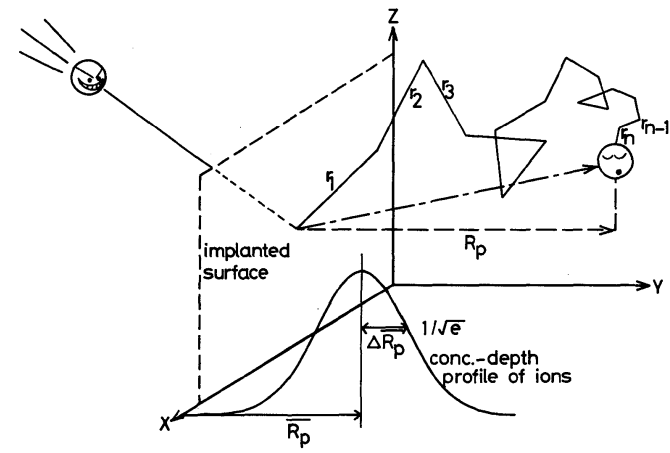

図 1 ターゲット中に注入されたイオンの軌跡と注入分布に持 ける $\bar{R}_{\mathrm{p}}$ と $\Delta \bar{R}_{\mathrm{p}}$ の定義。

\section{文献}

1) J.F. Gibbons, W.S. Johnson and S.W. Mylroie ; PROJECTED RANGE STATISTICS-Semiconductors and Related Materials--, 2 nd. (Dowden, Hutchinson and Ross, Inc., 1975)

2) G. Dearnaley, J.H. Freeman, R.S. Nelson and J. Stephen ; ION IMPLANTATION, p. 766 (North-Holland Pub. Co., Amsterdam, 1973)

(埼玉工業大学 岡部芳雄) 